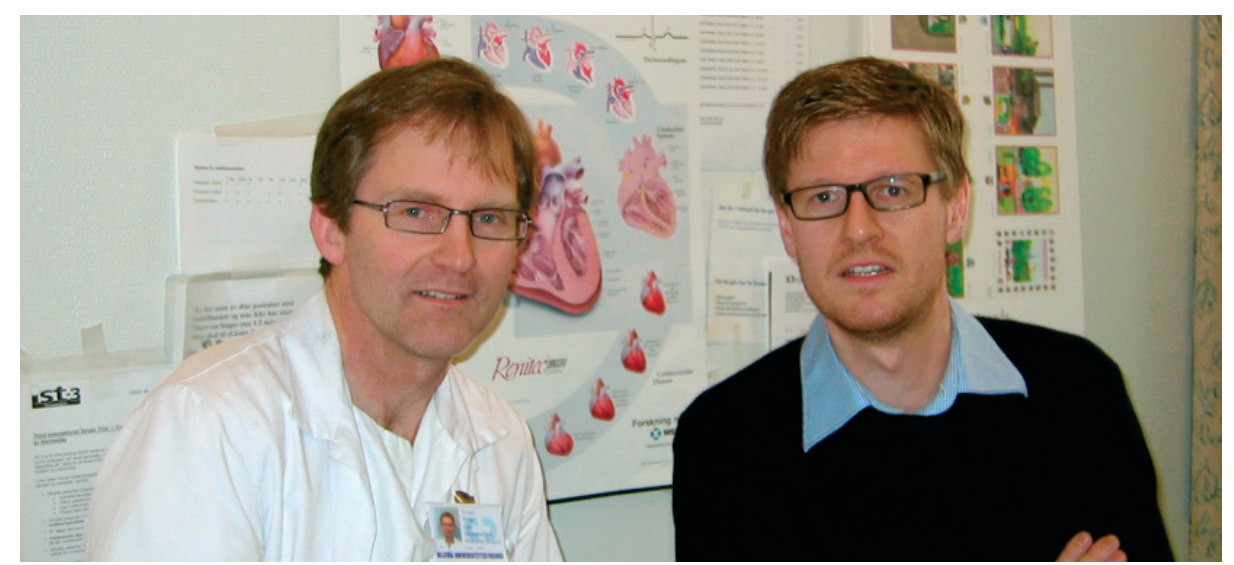

De norske medforfatterne Eivind Berge og Karsten Bruins Slot (til høyre). Foto Serap Karaagac

\title{
Mer bruk av trombolytisk behandling ved hjerneinfarkt
}

Behandling med intravenøs alteplase bør tilbys også ved alvorlige

hjerneslag og til pasienter over 80 år, ifølge ny studie.

Trombolytisk behandling med intravenøs rekombinant human vevsplasminogenaktivator (r-tPA, alteplase) brukes ved akutt iskemisk hjerneslag. Den europeiske lisensen inneholder flere restriksjoner, bl.a. må behandlingen starte innen 4,5 timer fra symptomstart, den skal ikke gis ved lette og alvorlige hjerneslag, og kun til pasienter under 80 år. Disse begrensningene er én av årsakene til at trombolytisk behandling fortsatt er lite brukt i klinisk praksis.

I Third International Stroke Trial (IST-3) ønsket man å undersøke om intravenøs alteplase bør tilbys pasienter som faller utenfor disse kriteriene, f.eks. pasienter med symptomvarighet inntil seks timer, pasienter som er eldre enn 80 år, og de med alvorlige hjerneslag (1).

Studien omfattet 3035 pasienter i 12 land. De ble randomisert til enten behandling med intravenøs alteplase eller til standard beste slagbehandling alene. Mer en halvparten av pasientene var eldre enn 80 år, og en tredel fikk behandling 4,5-6 timer etter symptomdebut. Den primære effektvariabelen var funksjonsnivå målt ved hjelp av Oxford Handicap Score (OHS) etter seks måneder. Den primære analysen av andelen pasienter med godt utfall (OHS 0-2) viste en ikkesignifikant forskjell i favør av alteplase (OR 1,13). En prespesifisert analyse av andelen pasienter med OHS $0-1$ og en prespesifisert ordinal regresjonsanalyse viste imidlertid begge en signifikant forskjell. Intrakraniale blødninger forekom oftere $i$ alteplasegruppen, men dette førte ikke til et økt antall dødsfall sammenliknet med kontrollgruppen etter seks måneder.

- Subgruppeanalyser viste at effekten av alteplase var minst like god hos pasienter som var eldre enn 80 år og hos dem med alvorlige hjerneslag, som hos andre grupper, sier Karsten Bruins Slot, en av de norske forfatterne. Analysene viste også at effekten er klart størst i løpet av de første tre timene etter symptomdebut, og viste ingen statistisk signifikant effekt i gruppen av pasienter inkludert i tidsrommet 4,5-6 timer.

- IST-3 er den hittil største randomiserte studien av trombolytisk behandling ved hjerneinfarkt. Resultatene bekrefter at intravenøs alteplase er effektivt ved akutt hjerneslag, spesielt i løpet av de første tre timer, og at behandlingen bør tilbys også pasienter som er eldre enn 80 år, og pasienter med alvorlige hjerneslag, sier Bruins Slot.

\section{Forskergruppen}

IST-3 utgikk fra Division of Clinical Neurosciences ved University of Edinburgh, og ble finansiert av Medical Research Council i Storbritannia, med økonomiske bidrag bl.a. fra Norges forskningsråd og Oslo universitetssykehus. I Norge ble til sammen 204 pasienter inkludert, ved sykehusene i Asker/Bærum, Harstad, Kongsvinger, Levanger, Namsos, Oslo (Ullevål), Tromsø, Trondheim, Volda og Ålesund. Norske koordinatorer og medforfattere var Eivind Berge og Karsten Bruins Slot ved Oslo universitetssykehus, Ullevål.

\section{Erlend Hem}

erlend.hem@medisin.uio.no

Tidsskriftet

\section{Litteratur}

1. The benefits and harms of intravenous thrombolysis with recombinant tissue plasminogen activator within $6 \mathrm{~h}$ of acute ischaemic stroke (the third international stroke trial [IST-3]): a randomised controlled trial. Lancet 2012; e-publisert 23.5.
Ordforklaringer

Iskemisk hjerneinfarkt: Hjerneskade forårsaket av en blodpropp i en av hjernens blodårer Iskemiske hjerneslag utgjør 85-90\% av alle hjerneslag, og er den viktigste årsak til funksjonshemning i den vestlige verden.

Alteplase: En substans (glykoprotein) som kan løse opp blodpropper. Alteplase ble i 2002 godkjent av det europeiske legemiddelverket (European Medicines Agency) for intravenøs behandling av akutt iskemisk hjerneinfarkt.

Oxford Handicap Score (OHS): En skala som brukes til å måle pasienters funksjonsnivå etter et hjerneslag. Skårene 0-2 indikerer at pasienter er funksjonelt selvhjulpne i dagliglivet; skårene 3-5 indikerer at pasienter er avhengige av hjelp fra andre. OHS er en variant av den mer kjente modifisert Rankin-skala.

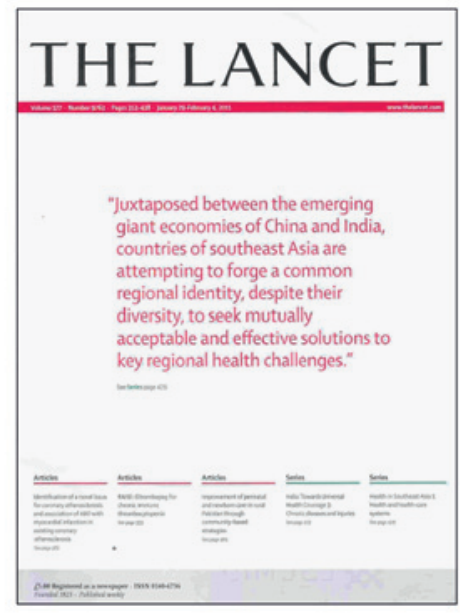

Artikkelen ble e-publisert 23.5. 2012 i The Lancet (www.thelancet.com), som regnes som en av de «fem store» innen medisinsk publisering ved siden av New England Journal of Medicine, JAMA, Annals of Internal Medicine og BMJ. 